\title{
Sugarcane Grub, Tomarus subtropicus Blatchley (Insecta: Coleoptera: Scarabacidae) ${ }^{1}$
}

Eileen A. Buss ${ }^{2}$

\section{Introduction}

Nine species of Tomarus Erichson (formerly Ligyrus Burmeister) occur in the United States, only four of which occur in Florida, including T. gibbosus DeGeer, T. cuniculus (Fabricius), T. neglectus LeConte, and T. subtropicus (Blatchley). Tomarus subtropicus is native to Florida, where it is a turfgrass pest and the most important sugarcane pest.

\section{Distribution}

Tomarus subtropicus has been collected from Alachua, Charlotte, Dade, Hillsborough, Lee, Manatee, Monroe, Palm Beach, Pinellas, and Sarasota Counties in Florida. Its range extends along the seacoast from North Carolina to Florida to Alabama.

\section{Description}

This adult description is from Cartwright (1959). "Adults: length 21 to $25 \mathrm{~mm}$, width 12 to 14 $\mathrm{mm}$. Oblong, convex, shining rufopiceous to piceous. Clypeus apically bidentate, the upturned, triangular teeth nearly contiguous at base, surface finely moderately closely rugose, the frontal carina represented by two low, widely spaced, more or less conical tubercles; front of head similarly rugose and slightly concave, the rugulose lines breaking to fine punctures posteriorly, occiput smooth. Pronotum convex with a low denticle on the anterior margin at middle and a flattened area or shallow depression behind it, the depression about one-third the pronotal length; sides margined, arcuate to acute anterior angles, base sinuate without margin; surface finely punctate over disc and at middle of base and sides, gradually much more coarsely punctate to the anterior and posterior angles, fine punctures at base separated by four or more diameters, coarse punctures in anterior angles generally by one diameter or less, the apical anterior depression rugose-punctate. Scutellum smooth or with a few fine punctures. Elytral sides sub-parallel, surface moderately coarsely punctate with very fine punctures intermixed throughout, the coarse, annular punctures of the oblique geminate striae and the intervals between somewhat coarser than those in the wide interval between the first geminate and sutural stria, all punctures finer and closer at sides and apex. Pygidium widely scabriculate-punctate at base and

1. This document is EENY-318, one of a series of Featured Creatures from the Entomology and Nematology Department, Florida Cooperative Extension Service, Institute of Food and Agricultural Sciences, University of Florida. Published: December 2003. This document is also available on Featured Creatures Website at http://creatures.ifas.ufl.edu. Please visit the EDIS Website at http://edis.ifas.ufl.edu. Additional information on these organisms, including many color photographs, is available at the Entomology and Nematology Department website at http://entnemdept.ifas.ufl.edu/. 2. Eileen A. Buss, Department of Entomology and Nematology, Institute of Food and Agricultural Sciences, University of Florida, Gainesville, FL.

The Institute of Food and Agricultural Sciences (IFAS) is an Equal Employment Opportunity - Affirmative Action Employer authorized to provide research, educational information and other services only to individuals and institutions that function without regard to race, creed, color, religion, age, disability, sex, sexual orientation, marital status, national origin, political opinions or affiliations. For information on obtaining other extension publications, contact your county Cooperative Extension Service office. Florida Cooperative Extension Service / Institute of Food and Agricultural Sciences / University of Florida / Larry R. Arrington, Interim Dean 
sides, only slightly less so in the female, otherwise shining and smooth with scattered very fine punctures, extreme apex virtually impunctate. Underside sparsely hairy anteriorly. Apex of prosternal process behind anterior coxae nude, smooth, only slightly convex, with the long, stiff hairs invading the area from sides and rear. Anterior tibia smooth and carinate outside the longitudinal row of coarse, setigerous punctures, claws unmodified. Male aedeagus distinct."

This larval description is from Gordon and Anderson (1981): "Mature larva about $50 \mathrm{~mm}$ long, head 8.0 to $8.5 \mathrm{~mm}$ wide. Head medium brown, surface distinctly roughened, with a few small pits. One pair of ocelli present. Frontal setae absent, except for 3 or 4 anterolateral angles. Terminal segment of antenna with 4 to 7 dorsal and 6 to 8 ventral sensory spots. Epipharynx with haptomeral process bearing 2 distinct marginal notches, and without plegmatia or proplegmatia. Inner margin of left mandible with 3 distinct scissorial teeth; third tooth more vaguely indicated on right mandible. Ventral manibular stridulatory area present. Claws stout, tapered to a point, bearing 2 setae. Raster of abdomen bearing a subtriangular patch of about 50 erect hamate setae, but no rows of pali. Lower anal lip bearing a mixture of hamate and long, straight setae. Anal opening a curved, transverse slit."

\section{Life Cycle}

This scarab beetle has a one year life cycle. Peak adult emergence occurs in May and June, but adults may be present from April through June. Eggs are white, spherical to ovoid in shape, and increase in size as the embryo grows and takes in water. Eggs may be present from June to July. Small grubs are dark gray and become whiter as as they molt and grow. Head capsule width is more reliable in determining grub instars than grub weight or length. Third instar (mature) grubs are present from October to April, and are nearly 2 inches long. Pupae are tan to brown, and occur deeper in the soil in earthen chambers. Adult beetles are a rusty-red color just after emerging from the pupal stage, but turn nearly black. Males and females are similar in size ( 1 inch long).

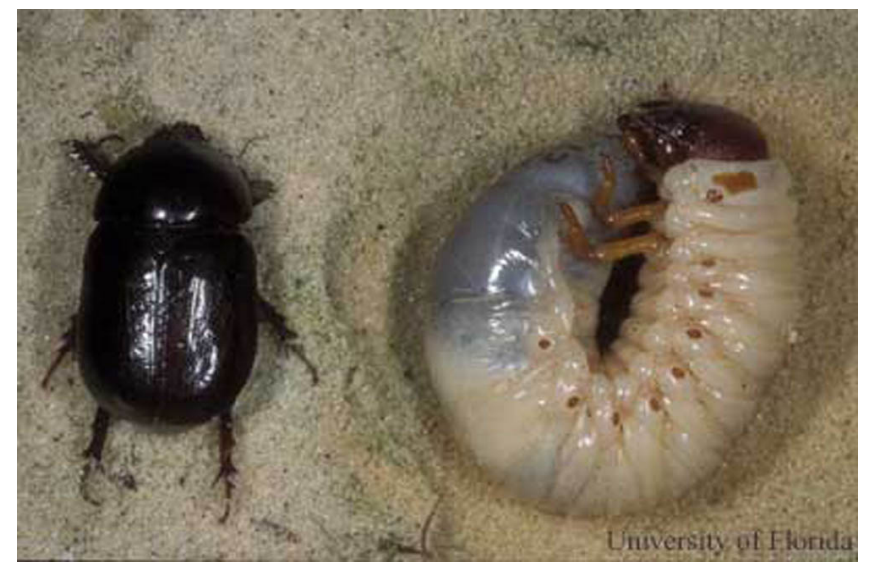

Figure 1. Tomarus subtropicus (Blatchley) adult (left) and mature grub (right). Credits: Photograph by: Lyle J. Buss and Eileen A. Buss, University of Florida

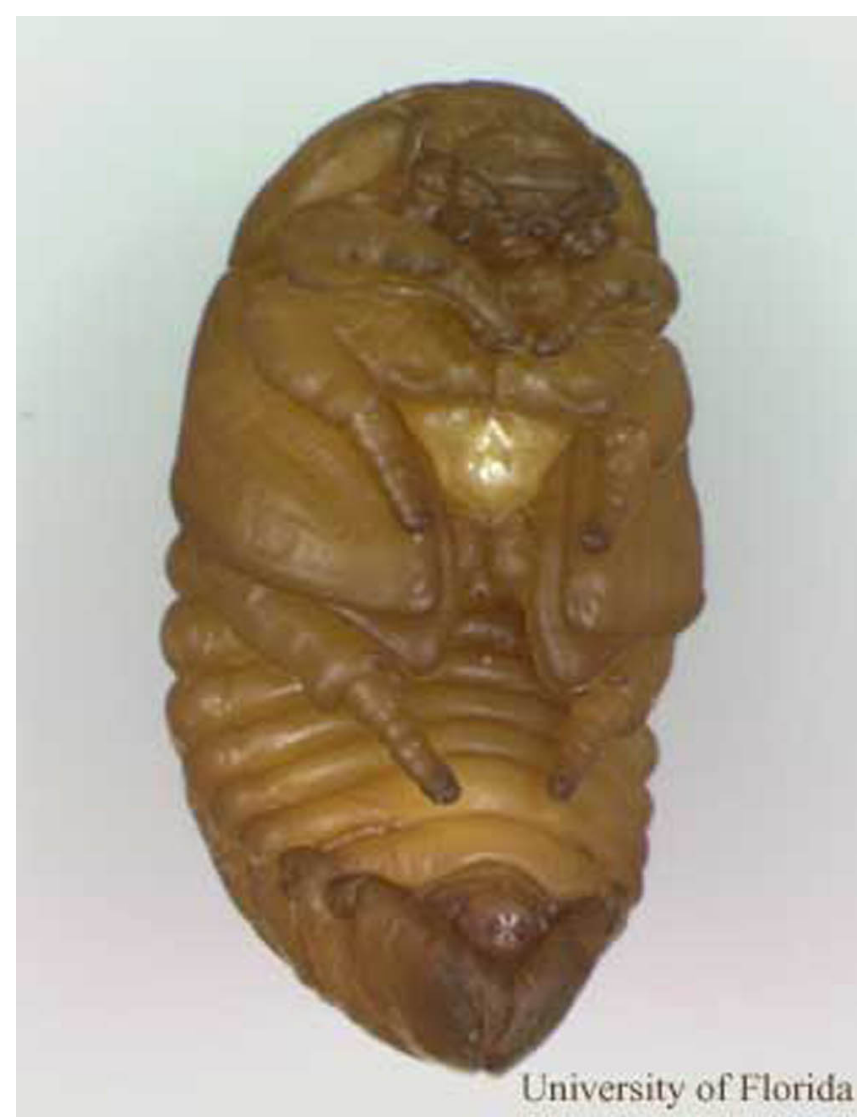

Figure 2. Pupa of Tomarus subtropicus (Baltchley). Credits: Photograph by: Lyle J. Buss and Eileen A. Buss, University of Florida

\section{Host Range}

Sugarcane, St. Augustinegrass, bahiagrass, bermudagrass, and possibly roots of ornamental plants. 


\section{Damage}

These white grubs feed on plant root systems, and appear to be most damaging on St. Augustinegrass lawns along the Gulf Coast in Florida and wherever sugarcane is grown. Entire root systems can be consumed by these grubs. The grass feels spongy when walked upon and can be easily lifted up. Grass may begin dying back in September. Grubs have been observed still feeding in the root zone (upper 1 to 3 inches of soil) in January in the greater Tampa area. Birds, armadillos, and other vertebrates may dig in the soil to feed on the grubs, causing further damage to the grass. Adults make mounds when emerging from the soil and when digging into the soil to lay eggs.

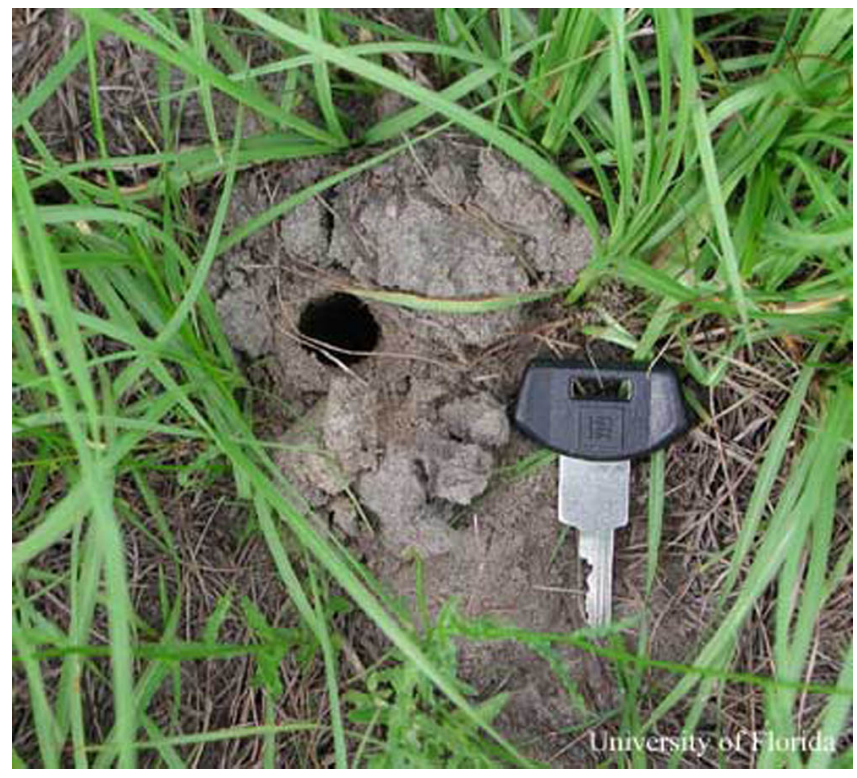

Figure 3. Mound made by Tomarus subtropicus (Blatchley) adult in bahiagrass and sandy soil. Car key was used to indicate size. Credits: Photograph by: Lyle J. Buss and Eileen A. Buss, University of Florida

\section{Natural Enemies}

Several pathogens have been isolated from $T$. subtropicus larvae, including Bacillus popilliae, Metarhizium anisopliae, Beauveria bassiana, and Verticillium lecontei, however, infection rates are usually low ( $<10 \%)$. Insect-parasitic nematodes, such as Steinernema glaseri (Steiner), may also attack $T$. subtropicus larvae, pupae, and adults. The predator and parasitoid complex is unknown.

\section{Management}

Based on the known life cycle, the optimal timing for a preventative treatment to kill first instars is from May to June. However, several turfgrass managers have tried this and still get call-backs in September/October and additional grub damage. Several insecticides are available as curative controls for larger grubs. See White Grub Biology and Management (http://edis.ifas.ufl.edu/LH037).

Control of T. subtropicus in sugarcane is achieved by flooding, but this is not practical in urban landscape areas.

For additional information see:

Insect Management Guide in Sugarcane (http://edis.ifas.ufl.edu/BODY_IG065)

Insect Management Guide in Turfgrass (http://edis.ifas.ufl.edu/BODY_IG001)

\section{Selected References}

Boucias DG, Cherry RH, Anderson DL. 1986. Incidence of Bacillus popilliae in Ligyrus subtropicus and Cyclocephala parallela (Coleoptera: Scarabaeidae) in Florida sugarcane fields. Environmental Entomology 15: 703-705.

Cartwright OL. 1959. Scarab beetles of the genus Bothynus in the United States (Coleoptera: Scarabaeidae). Proceedings of the United States National Museum Vol. 108 (3409): 515-541.

Cherry RH. 1985. Seasonal phenology of white grubs (Coleoptera: Scarabaeidae) in Florida sugarcane fields. Journal of Economic Entomology 78: 787-789.

Endr"di S. 1985. The Dynastinae of the World. W. Junk. London, 800 pp.

Gordon RD, Anderson DM. 1981. The species of Scarabaeidae (Coleoptera) associated with sugarcane in South Florida. Florida Entomologist 64: 119-138.

Sosa Jr O, Hall DG. 1989. Mortality of Ligyrus subtropicus (Coleoptera: Scarabaeidae) by entomogenous nematodes in field and laboratory trials. Journal of Economic Entomology 82: 740-744. 